\title{
Trimmatostroma commonii, a new lichenicolous hyphomycete inhabiting Graphidaceae hosts
}

\author{
Paul Diederich ${ }^{1}$, Mikhail P. Zhurbenko ${ }^{2,3}$, Andrey N. Kuznetsov ${ }^{3,4} \&$ \\ Pieter van den Boom ${ }^{5}$ \\ ${ }^{1}$ Musée national d'histoire naturelle, 25 rue Munster, L-2160 Luxembourg, Luxembourg. \\ E-mail: paul.diederich@education.lu \\ ${ }^{2}$ Lab. of the Systematics and Geography of Fungi, Komarov Botanical Institute Russian Academy of Sciences, \\ Professor Popov 2, 197376 St. Petersburg, Russia. E-mail: zhurb58@gmail.com \\ ${ }^{3}$ Joint Vietnam-Russian Tropical Scientific Research and Technological Centre, Nguyen Van Huyen, \\ Nghia Do, Cau Giau, Hanoi, Vietnam. \\ ${ }^{4}$ Lab. of the Tropical Ecology, A.N. Severtsov Institute of Ecology and Evolution, Russian Academy of Sciences, \\ Leninskiy Prospekt 33, 119071 Moscow, Russia. E-mail: forestkuz@mail.ru \\ ${ }^{5}$ Arafura 16, 5691JA Son, The Netherlands. E-mail: pvdboom@kpnmail.nl
}

\begin{abstract}
The new lichenicolous hyphomycete Trimmatostroma commonii is described from Réunion, the USA (Florida) and Vietnam. It strongly resembles the generic type T. salicis, from which it is distinguished by much looser conidiomatal tufts, less septate conidia and the lichenicolous habitat, growing over species of Graphidaceae in the tropics.
\end{abstract}

Published: 8 May 2020

\section{INTRODUCTION}

The genus Trimmatostroma Corda includes hyphomycetes with simple, little differentiated conidiophores and conidiogenous cells, and polymorphous conidia formed in basipetal chains; it includes c. 30 mostly bark-inhabiting, but also aquatic saprobic species, and additionally a number of lichen-inhabiting taxa. The type species $T$. salicis Corda, a bark-inhabiting saprobic microfungus, has pulvinate, sometimes confluent sporodochia, and conidiophores originating from a basal stroma (Ellis, 1971); it was included in a phylogenetic analysis and found to belong to the Mollisiaceae in the Helotiales (Hernández-Restrepo et al., 2017). Diederich et al. (2010) described four new Trimmatostroma species growing on lichens and presented a key to identify them, Zhurbenko \& Brackel (2013) added one species, and Heuchert \& Braun (2014) described two more, together with an updated key to seven lichenicolous species. Two additional species were eventually described by Brackel (2015) and Schiefelbein et al. (2017), resulting in eight obligately and one facultatively lichenicolous Trimmatostroma species accepted by Diederich et al. (2018). These nine taxa represent a heterogeneous assemblage of morphologically similar species of which at least some are almost surely not related to the generic type. Here we describe a further lichenicolous species in Trimmatostroma that strongly resembles the generic type and might therefore be phylogenetically related to it. Unfortunately, no molecular data have ever been obtained from any of these lichenicolous species.

\section{MATERIAL AND METHODS}

The specimens examined are deposited in BR and LE, and in the private herbaria of P. Diederich and P. van den Boom. Dry herbarium specimens were examined and measured under a binocular microscope Leica MZ 7.5 (magnification up to $\times 50$ ), and photographed using a Canon 40D camera with a Nikon BD Plan 10 microscope objective, StackShot (Cognisys) and Helicon Focus (HeliconSoft) for increasing the depth of field. Small fragments or sections of conidiomata were studied in water, without or after a slight pressure on the cover glass, and in $5 \% \mathrm{KOH}$. The material from Vietnam was studied using a Stemi 2000-CS stereo microscope and a Zeiss Axio Imager A1 compound microscope equipped with Nomarski differential interference contrast optics.

Microscopic photographs were prepared using a Leica DMLB microscope, a Leica EC3 camera and Helicon Focus. Conidial measurements are 
indicated as (min.- $) \mathrm{X}-\sigma_{\mathrm{x}}-\mathrm{X}+\sigma_{\mathrm{x}}(-\max$ ) , followed by the number of measurements (n). Chemical reactions were tested using $5 \% \mathrm{KOH}(\mathrm{K})$.

\section{RESULTS}

Trimmatostroma commoni Diederich, Zhurb. \& van den Boom sp. nov. (Fig. 1)

MycoBank number: MB835494

Diagnosis. Similar to Trimmatostroma salicis, but differs by the much looser conidiomatal tufts, the less septate conidia and the lichenicolous lifestyle.

Type. Réunion, W of Plaine des Palmistes, along the road to Forêt de Bébour, $21^{\circ} 08.50^{\prime}$ 'S, $55^{\circ} 35.20^{\prime} \mathrm{E}$, elev. $1220 \mathrm{~m}$, Cryptomeria japonica forest, on Phaeographis (apothecia, thallus) and occasionally on adjacent bark, 26 May 2008, P. \& B. van den Boom 39750 (BR - holotype, herb. Diederich, herb. van den Boom - isotypes).

Description. Colonies lichenicolous, over the thallus of corticolous Graphidaceae, black, caespitose or in erect tufts, mostly 100-400 $\mu \mathrm{m}$ diam., conidiophores rather dense, visible at a very high magnification $(\times 50)$. Mycelium internal, hyphae branched, $2.5-5 \mu \mathrm{m}$ wide, pale brown, septate, thin-walled, smooth, superficial hyphae not formed. Stromata rather reduced, composed of swollen hyphal cells, subglobose or slightly elongate, 4-8 $\mu \mathrm{m}$ diam., pale to medium brown, smooth, wall 0.5-1 $\mu \mathrm{m}$ thick. Conidiophores immersed to erumpent, micronematous or semi-macronematous, erect, ca. $20-40 \times$ 6-8 $\mu \mathrm{m}$, hyphal filaments suddenly developing into fertile threads by becoming wider and darker, with a distinctly thicker wall, smooth or slightly rough, reduced to conidiogenous cells, or conidiogenous cells integrated, terminal, little differentiated, conidiogenous loci undifferentiated, subtruncate. Conidia in simple or rarely branched, irregular, easily disarticulating basipetal chains, straight or slightly curved, oblong, basally truncate, apically rounded or truncate, hila unthickened and not darkened, transversely (0-)1-pluriseptate, with septa occasionally oblique, (4.5-)5.1-6.7(-7.8) $\mu \mathrm{m}$ wide $(\mathrm{n}=114), 1$-septate conidia (6.6-)7.5-10.3(-12) $\mu \mathrm{m}$ long $(\mathrm{n}=20), 2$-septate (9.6-) 10.5-12.7(-13.7) $\mu \mathrm{m}(\mathrm{n}=20), 3$-septate (11-)13.2-17.1(-21.3) $\mu \mathrm{m}$ $(\mathrm{n}=24)$, 4-septate (13.7-)15.1-19.0(-20.7) $\mu \mathrm{m}$ $(\mathrm{n}=20)$, 5-septate $(10.5-) 15.5-21.9(-23.2) \mu \mathrm{m}$ $(\mathrm{n}=20), 6$-septate (19.7-)20.7-25.5(-27.7) $\mu \mathrm{m}$ $(\mathrm{n}=10)$, medium to dark brown, becoming dark violet brown to blackish in $\mathrm{KOH}$, ends more or less rounded, wall $0.5-1 \mu \mathrm{m}$ thick, smooth or slightly rough, septa $1-1.5 \mu \mathrm{m}$ thick; some conidia apparently meristematic, producing secondary conidia at their ends, superficially resembling acropetal chains; conidia often enteroblastically proliferating (rejuvenation) with obvious sheath-like wall remnants visible as an irregular fringe.

Etymology. Trimmatostroma commonii is named after Ralph Common, an enthusiastic American lichenologist and a remarkable collector of lichenicolous fungi, who kindly sent us his recent Florida specimen of the new species and allowed us to describe it.

Distribution and hosts. The new species is currently known from Réunion (Mascarene Islands, Indian Ocean), Vietnam and the USA (Florida). It grows on corticolous Graphidaceae, including Graphis and Phaeographis species, not visibly damaging the hosts. The species has been observed growing on the thallus and apothecia of the hosts, on hypothallus lines, and on minuscule bark outgrowths within lichen thalli, sometimes not distinctly lichenicolous. We consider it as a poorly host-specific species that may also grow on the bark very close to infected thalli.

Notes. Microscopically, the new species strongly resembles the generic type, Trimmatostroma salicis; that species differs by much more compact and well delimited sporodochia, up to 13-septate conidia and by being non-lichenicolous, known exclusively from Salix twigs and branches (Ellis 1971, Crous et al. 2007). With the description of a new species, the genus Trimmatostroma now includes 10 lichenicolous species, of which nine are considered as obligately lichenicolous, and one as facultatively lichenicolous. Keys to lichenicolous species were given by Diederich et al. (2010) and Heuchert \& Braun (2014). Most other lichenicolous species are distinguished by conidiophores not forming tufts, by ornamented conidia, or by a different reaction of the conidial pigment with $\mathrm{KOH}$. Trimmatostroma hierrense Diederich \& Ertz is distinguished by an unevenly thickened conidial wall. All these species also inhabit other host lichens belonging to the Arthoniales, Lecanorales, Pertusariales and Umbilicariales. 

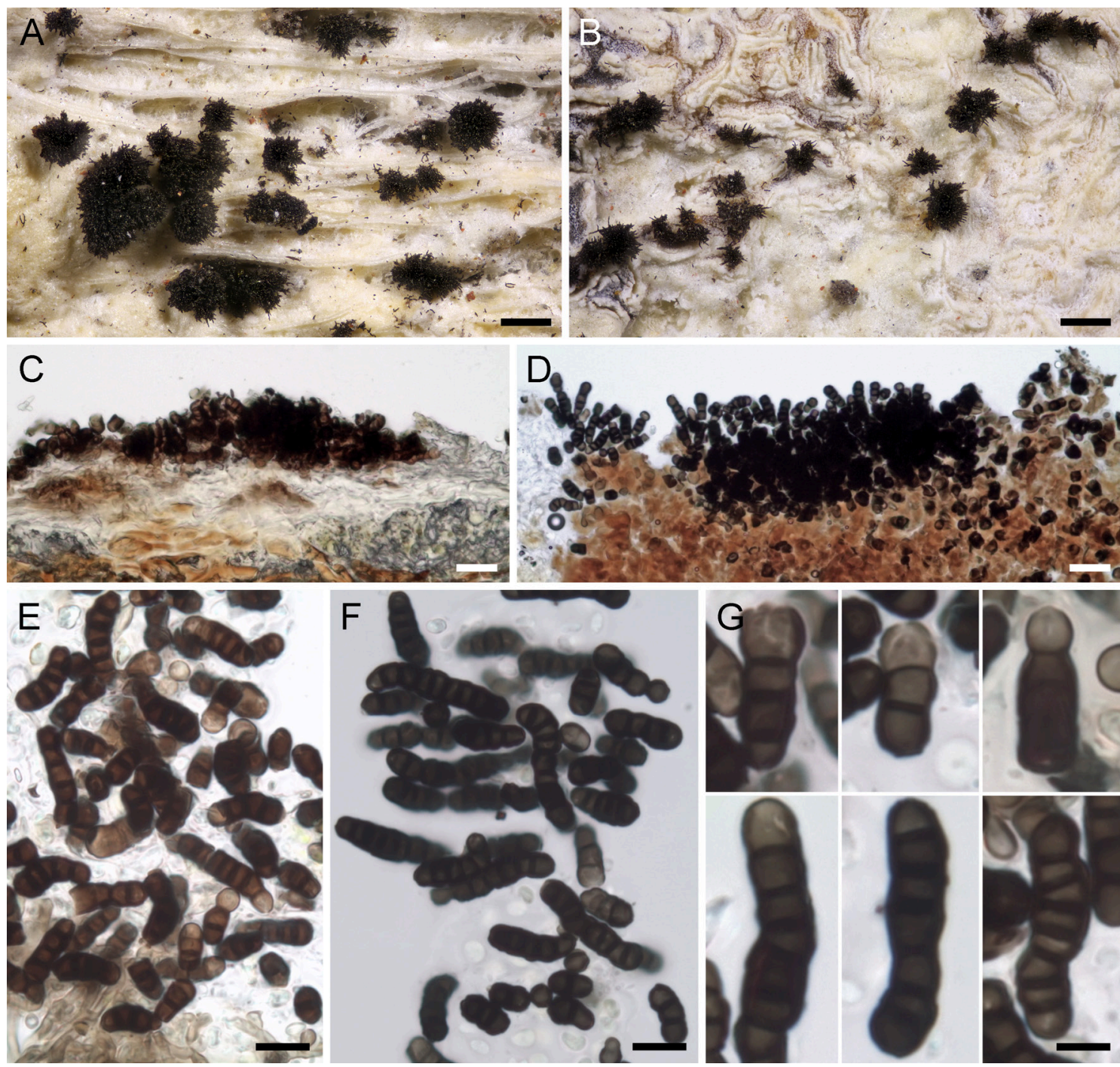

Fig. 1. Trimmatostroma commonii (all BR - holotype, except C: Common 10118B). A, B - colonies over thallus and apothecia of Phaeographis; C - section through young conidioma, in water; D section through conidioma, in $\mathrm{KOH}$; $\mathrm{E}$ - conidia, in water; F, G-conidia in $\mathrm{KOH}$ (scale bars: A, B $=200 \mu \mathrm{m}, \mathrm{C}, \mathrm{D}=20 \mu \mathrm{m}, \mathrm{E}, \mathrm{F}=10 \mu \mathrm{m}, \mathrm{G}=5 \mu \mathrm{m})$.

Additional specimens examined. Vietnam: Northeast Region, Cao Bằng Province, Nguyên Bình District, Phia Oắc-Phia Đén National Park, $4.8 \mathrm{~km} \mathrm{SW}$ of Tinh Tuc village, $22^{\circ} 36^{\prime} 28^{\prime \prime} \mathrm{N}, 1^{\circ} 5^{\circ} 51^{\prime} 59^{\prime \prime} \mathrm{E}$, elev. $1700 \mathrm{~m}$, montane evergreen broad-leaved forest near road, on corticolous Graphis (thallus), 7.06.2019, L. V. Gagarina (LE 310090). USA: Florida, Hillsborough Co., near Morris Bridge Road, $28.115^{\circ} \mathrm{N}, 82.301^{\circ} \mathrm{W}$, on Phaeographis (thallus) and occasionally on adjacent bark, 2016, R. Common 10118B (herb. Diederich).

\section{ACKNOWLEDGMENTS}

We are most thankful to Ralph Common for sending us his specimen of the new species from Florida. M. P. Zhurbenko is grateful to Ludmila V. Gagarina for permission to search for lichenicolous fungi in her lichen collection from Vietnam. The studies of M. P. Zhurbenko were carried out within the framework of the research 
project of the V. L. Komarov Botanical Institute of the Russian Academy of Sciences "Taxonomic diversity, ecology and physiological and biochemical features of fungi and fungus-like protists of Vietnam" (AAAA-A19-119080990059-1) using equipment of its Core Facility Center "Cell and Molecular Technologies in Plant Science". The field work of M. P. Zhurbenko and L. V. Gagarina in Vietnam, including collecting permits, was supported by the administrations of the Joint Russian-Vietnamese Tropical Scientific Research and Technological Centre and Chu Yang Sin and Phia Oắc-Phia Đén National Parks, and personally by Svetlana P. Kuznetsova, Nguen Dang Hoi, Pham Hong Phuong and Le Xuan Son.

\section{REFERENCES}

Brackel, W. von. 2015. Lichenicolous fungi from Central Italy with notes on some remarkable hepaticolous, algicolous and lichenized fungi. Herzogia 28: 212-281. https://doi.org/10.13158/ heia.28.1.2015.212

Crous, P. W., Braun, U. \& Groenewald, J. Z. 2007. Mycosphaerella is polyphyletic. Studies in Mycology 58: 1-32. https://doi.org/10.3114/ $\operatorname{sim} .2007 .58 .01$

Diederich, P., Braun, U., Heuchert, B. \& Ertz, D. 2010. Four new lichen-associated Trimmatostroma spe- cies (hyphomycetes). Bulletin de la Société des naturalistes luxembourgeois 111: 47-55.

Diederich, P., Lawrey, J. D. \& Ertz, D. 2018. The 2018 classification and checklist of lichenicolous fungi, with 2000 non-lichenized, obligately lichenicolous taxa. The Bryologist 121: 340-425. https://doi. org/10.1639/0007-2745-121.3.340

Ellis, M. B. 1971. Dematiaceous hyphomycetes. Commonwealth Mycological Institute, Kew.

Hernández-Restrepo, M., Gené, J., Castañeda-Ruiz, R. F., Mena-Portales, J., Crous, P. W. \& Guarro, J. 2017. Phylogeny of saprobic microfungi from Southern Europe. Studies in Mycology 86: 53-97. https://doi.org/10.1016/j.simyco.2017.05.002

Heuchert, B. \& Braun, U. 2014. Two new lichenassociated Trimmatostroma species. Herzogia 27: 227-236. https://doi.org/10.13158/ heia.27.2.2014.227

Schiefelbein, U., Brackel, W. von, Cezanne, R., Czarnota, P., Eckstein, J., Eichler, M., Kison, H.-U., Ungethüm, K. \& Stordeur, R. 2017. Trimmatostroma arctoparmeliae sp. nov. and noteworthy records of lichenized, lichenicolous and allied fungi from the Harz Mountains and surrounding regions. Herzogia 30: 80-102. https://doi.org/10.13158/ heia.30.1.2017.80

Zhurbenko, M. P. \& Brackel, W. von. 2013. Checklist of lichenicolous fungi and lichenicolous lichens of Svalbard, including new species, new records and revisions. Herzogia 26: 323-359. https:/ / doi. org/ 10.13158/heia.26.2.2013.323 